\title{
The Subak in Diaspora: Balinese Farmers and the Subak in South Sulawesi
}

\author{
Dik Roth
}

Published online: 13 January 2011

(C) The Author(s) 2011. This article is published with open access at Springerlink.com

\begin{abstract}
The subak has a long history as an irrigators' institution on Bali. It has also spread across Indonesia along with Balinese farmers who were resettled by colonial and post-colonial governments or who have migrated spontaneously since colonial times. While subaks have been much researched in Bali itself, little is known about subaks outside Bali. Luwu District in South Sulawesi is one of the areas where thousands of Balinese families settled in the last four decades. Based on research in this transmigration area, this paper analyzes the emergence and development of the subak in relation to the development of irrigation infrastructure of a state-built irrigation system. A comparison between two Balinese settlements in the same system shows that differences in infrastructural and managerial conditions and arrangements between parts of the irrigation system were major determinants of the institutional space allowed for the subak and ways in which the subaks developed.
\end{abstract}

Keywords Subak · Irrigation management - Tertiary unit (TU) · Water users' association (WUA) · Transmigration

\section{The Balinese Subak: From 'Local Tradition' to Migrant Institution}

The Balinese Subak

The subak is a widely known 'traditional' irrigation management institution for rice cultivation on the Indonesian

D. Roth $(\bowtie)$

Wageningen University,

Wageningen, the Netherlands

e-mail: dik.roth@gmail.com island of Bali. It has developed over the centuries in the specific socio-cultural, agro-ecological and politicaladministrative environment of this small and mountainous island. As a consequence, the subak and irrigated rice agriculture became well adapted to, and embedded in the characteristic Balinese landscape of rugged mountains and steep valleys deeply incised by fast-flowing rivers.

Since colonial times, however, the subak has also spread across the Indonesian archipelago, along with Balinese farmers resettled by colonial and post-colonial governments or those who migrated spontaneously. While part of the population of Bali itself has gradually moved away from irrigated rice agriculture and become increasingly dependent on income from tourism and other economic activities outside agriculture, migrant Balinese often started a new life in rural areas where they could acquire more land than they had ever possessed on Bali, so that the cultivation of irrigated rice became and remained their first source of livelihood. In this article I discuss the emergence and development of subaks among Balinese migrants in the command area of the Kalaena irrigation system in North Luwu, South Sulawesi Province.

Since the colonial period, the subak in Bali has been intensively studied by researchers with a variety of academic and other interests and objectives in different time periods, from different disciplinary backgrounds and taking various approaches. The subak has a long history: first mention of it was made some 900 years ago, but it is not something that belongs to the past. In the 1980s Bali still counted more than 1,200 subaks covering a total irrigated area of 100,000 ha (Sutawan et al. 1990). However, developments in the last decades, primarily the rapidly increasing use of land and water resources for nonagricultural purposes (human settlement, tourism) have 
become a major threat to the continued existence of the subak in many areas of Bali.

From colonial times, the importance of subak as an institution with both secular and religious-ritual functions related to irrigated agriculture, was recognized by outside observers. Many authors in the colonial period stressed 'subak autonomy', its relative independence of other local or higher-level political and administrative institutions, and its key role in Balinese irrigation (Korn 1924; Liefrinck 1969; see Lansing 1991). ${ }^{1}$ Dutch colonial administrators and engineers (e.g., Happé 1935) were interested in the subak as a potential model for irrigation management on the neighboring island of Java. Colonial debates also concerned the advantages and disadvantages of subak water division technology based on continuous proportional irrigation, in comparison with modern engineering technology based on absolute and rotational forms of water division (see Booth 1977; Horst 1996).

After decolonization, subak continued to draw much attention, especially from anthropologists. Geertz (e.g., 1972, 1980) stressed the near-total local autonomy of the 'village republic', of which the subak was distinguished as a 'wet' variant (Boon 1977; Schulte Nordholt 1986). ${ }^{2}$ Later the focus shifted from exclusive attention to the subak, its organizational structure and functions, to higher levels of integration of which the subaks are part. Lansing analyzed the role of agricultural rituals as 'scheduling mechanism', and of regional networks of water temples as 'managers of the terrace ecosystems' (Lansing 1987, 327; 1991). Theories about the autonomy of the subak and associated assumptions about relationships between local society and the state (Balinese kingdoms) have been rightly criticized, as they sketch a distorted image of Balinese and subak history (Howe 2006; see Schulte Nordholt 1996). Lansing's approach has also been criticized for retrospectively ascribing all kinds of functions to the subak, primarily pest control (see Falvo 2000). ${ }^{3}$

In legal-anthropological approaches, the subak is no longer reduced to its formal properties, but more broadly analyzed in relation to actual behavior of actors in interaction settings where subak, government agencies and development programmes meet. Subak, its constituent

\footnotetext{
${ }^{1}$ Colonial intervention required strong local organization for irrigation management, agricultural production, administration and tax collection (Korn 1924; Lansing 1991).

2 As Geertz writes: 'A subak is, first and foremost ... a kind of "wet village", as opposed to the "dry" one in which people reside' (1972: 27).

${ }^{3}$ New functions continue to be 'invented' for, and projected onto, the subak. Thus, Sutawan (1998) pleads for the development of subak into a 'multipurpose institution' engaging in commercial agriculture and environmental protection of the catchment areas in which they are located.
}

parts, or higher integrative levels, and its normative-legal basis can become subject to differing definitions and interpretations, and thus undergo important transformations itself. From this perspective, approaches to 'the subak' as a discrete, unchanging 'traditional' institution were rightly criticized and confronted with the real world of living social actors and their struggles about rights and responsibilities in land and water management. The image of subak as an easily definable and bounded area of irrigated fields, as assumed by Geertz (1972), may well satisfy the need on the part of irrigation policy makers for a readily identifiable 'traditional' unit to concentrate their interventions on, but does not seem to reflect Balinese social reality (Spiertz 1991). ${ }^{4}$

An important contribution from the field of irrigation studies was made by Horst (1996), who analyzed the conflicts between subaks and government agencies caused by outside interventions in subak water division technology in the framework of development projects. As this paper will show, similar conflicts about and around technology can also be found in today's Balinese migrant settings.

\section{Balinese Migrants and the Subak}

In sharp contrast to all this Bali-focused work, very little is still known about subaks and their role in irrigation management in regions outside Bali, where Balinese have settled and become engaged in irrigated agriculture. Studies on the subak outside Bali show a strong geographical focus on the island of Sulawesi. Davis (1976) has done research on Balinese migration and settlement in the Poso region in Central Sulawesi, having its roots in a small group of Balinese exiled by the Dutch colonial government in the early twentieth century. Though Davis also discusses irrigated agriculture and the role of the subak, this is only a marginal theme in her study.

Charras (1982), writing on Luwu District, has further contributed to our understanding of general processes of adaptation by Balinese transmigrant farmers to nonBalinese social, cultural and agro-ecological environments. An important element of this adaptation, specific to pioneer settlement, is related to the transformation of the landscape from forest into (rainfed or irrigated) agricultural land. Charras discusses this process, which for Balinese is not only a physical transformation of the landscape, but also a process that has to be accompanied by appropriate ritual as it is considered full of dangers and threats associated with

\footnotetext{
${ }^{4}$ Spiertz applied this approach to the analysis of fields of interaction between subak and government programmes for rehabilitation and upgrading, operation and maintenance of irrigation systems. Here subak becomes a strategic 'resource' in processes of decision-making about financing of construction, operation and maintenance, and farmers' contributions of labour (Spiertz 1991).
} 
the spirit world. The subak, however, is not a primary topic of interest in this study either.

The first research with a more specific focus on irrigation and subak, again situated in (North) Sulawesi, is a comparative study of local irrigation management and the emergence of socially recognized water rights and allocation practices in two small Balinese irrigation systems by Vermillion (1986, 2000). Vermillion shows that irrigation practices are not fully determined by formal rules, but essentially involve processes of social interaction through which actualized water rights are constantly evolving. Norms, rules and regulations are 'resources' in processes of claim-making, negotiation, competition and adjustment between users on the basis of a variety of justifying criteria' (Vermillion 1986). Paying due attention to the relationship between rules and formal rights on one hand, and actual farmer behavior on the other, Vermillion stands very close to legal anthropological approaches to the study of subak and Balinese conceptualizations of water rights (see below). He studied the relationship between rules for water allocation and behavior in relatively small and socially homogeneous water management settings characterized by intensive daily interactions between irrigators who share important beliefs and norms. It is in these interactions that socially accepted water allocation practices emerge.

\section{Studying the Subak in Luwu}

My own research on the subak (see also Roth 2005, 2006) was also situated in Sulawesi. Like Charras, I did research on Balinese transmigrant settlements in Luwu District in South Sulawesi Province (see Fig. 1), with a focus on the use and management of natural resources (land and water). This research was part of a broader academic research agenda on rights to land and water in settings of irrigated agriculture where the definitions of such rights and related responsibilities may originate from a variety of state and non-state sources. Main objective of the research was to analyze the role of law, cultural norms and institutions in irrigated agriculture, focusing on state- and farmer-managed irrigation systems. It was inspired conceptually and theoretically by approaches that take into account the legally complex nature of the definitions of rights to natural resources and water infrastructure (and related responsibilities). 'Legal pluralism' refers to the existence and interaction of various (often state and non-state) legal orders or frameworks in one socio-political space (see von Benda-Beckmann et al. 1996; von Benda-Beckmann and von Benda-Beckmann 2006; Bruns and Meinzen-Dick 2000; Meinzen-Dick and Pradhan 2001; for legal anthropological work on Balinese irrigation, see Spiertz 1991, 2000).
My research was also inspired by Vermillion's work on Balinese irrigation systems (see above). His concepts of 'first approximation' (a share-based formal division of water) and 'second approximation' (socially accepted practices) parallel concepts like 'categorical property relationships' and 'concretized property relationships' in legal anthropology (von Benda-Beckmann et al. 2006), and 'reference rights' (water allocation), 'activated rights' (water scheduling) and 'materialized rights' (actual water distribution) in irrigation studies (Boelens and Zwarteveen 2002).

Approaches in irrigation studies that pay attention to the socially constructed nature of (irrigation) technology (Mollinga 2003; Vincent 2001; for Balinese irrigation, see Horst 1996; Spiertz 1991) formed another source of inspiration. Irrigation systems can be analyzed as 'sociotechnical systems', complexes of physical-technical, organizational and normative-legal dimensions of water control that develop in a wider agro-ecological, political-economic and socio-cultural context (see also Boelens 1998; Vincent 2001).

This article is based on a long period of field research among Balinese migrants in Luwu in the late 1990s. Important research methods were field observations, indepth interviews with, among others, farmers, village administrators, irrigation officials, managers of subaks and Water Users' Associations (WUAs), and village elders. I took observable changes in the water division technology of the irrigation system as a starting point for further research on the role and development of state and Balinese institutions for irrigation management, their interactions, and water use and management practices at the interface of such institutions.

After this introduction, in the second section I give a concise description of the general context of the study area and the specific conditions of emergence and development of subaks. The third section focuses on the establishment and development of subaks in the Balinese village of Kertoraharjo (Fig. 2) in relation to the process of irrigation infrastructure construction by the Public Works agency. The fourth section deals with changes in the definition of subak membership, in relation to broader processes of socioeconomic change that influence Balinese land tenure. The fifth section takes a comparative perspective. I will show that subaks in the village of Alam Buana, very close to Kertoraharjo, have developed quite differently from those in the latter village. The paper ends with a short conclusion on the role of subak in this migrant setting. I will argue that the subak is too diverse and adaptable an institution to form the basis of any a priori instrumental pronouncements pertaining to its assumed managerial efficiency, suitability for agricultural development, or supportive role to sustainability. 
Fig. 1 Indonesia, Bali, Sulawesi, Luwu and the Kalaena irrigation system
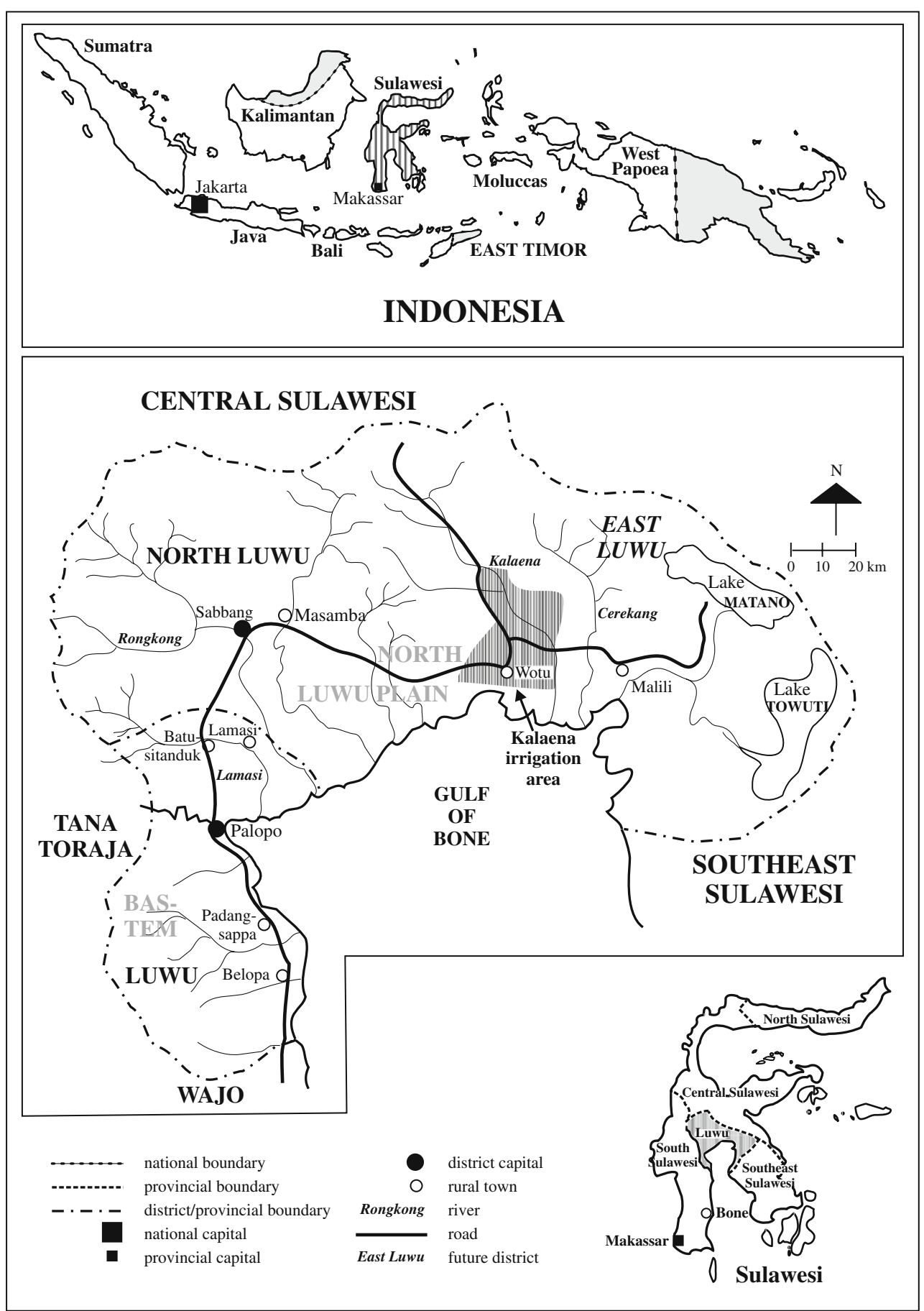

\section{Balinese Transmigration and the Subak in Luwu}

Luwu and Transmigration

Luwu is a largely mountain-covered region in the northeast of South Sulawesi Province. ${ }^{5}$ From colonial times onwards,

\footnotetext{
${ }^{5}$ Under the influence of recent political developments (regional autonomy, decentralization) Luwu District was subdivided into three new districts: Luwu, North Luwu and East Luwu. As this is not relevant here, I continue to speak of Luwu.
}

the coastal plains of northern Luwu, in particular, became a key area of land and water resources development. The rivers flowing into the North Luwu Plain make the area very suitable for irrigation development. Beginning in the 1930s, it became a destination for the Dutch "colonization" (kolonisasi) program through which Javanese (and, on other islands, Balinese) were resettled. ${ }^{6}$ The program's

\footnotetext{
${ }^{6}$ Note that 'colonization' here refers to pioneer land settlement, not to colonial rule.
} 
Fig. 2 Location of Kertoraharjo and Alam Buana in the Kalaena right-bank area

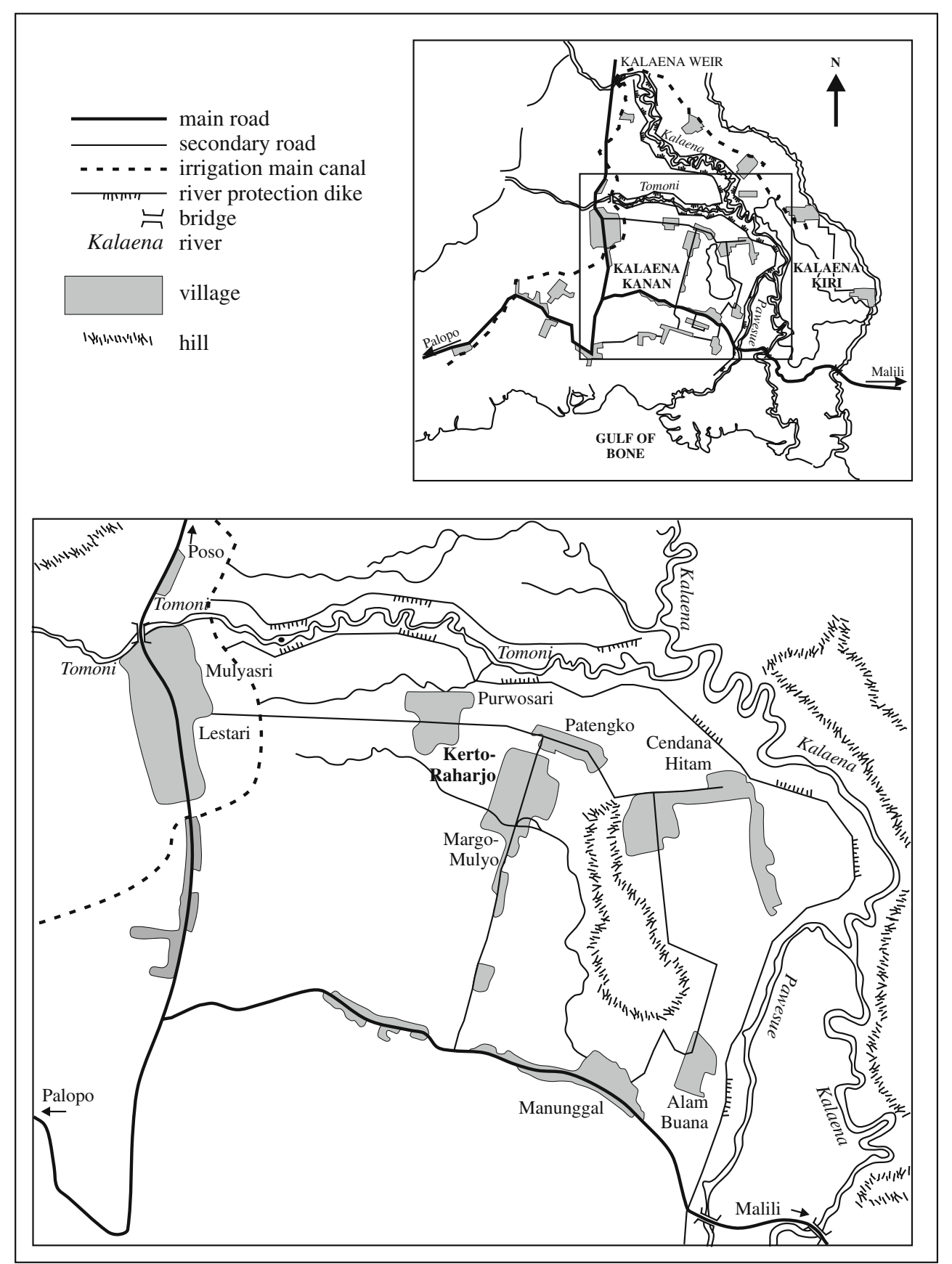

main objectives were poverty alleviation, reduction of population density on Java and Bali, and economic development of the "outer regions" of the Dutch colony. A key element was the creation of rural settlements based on irrigated agriculture, using the experience of Javanese and Balinese farmers.

After independence, the Indonesian transmigration program (transmigrasi) continued this policy. State-sponsored transmigration resettled mainly Javanese and Balinese farmer families on resource-abundant islands with a relatively low population density, such as Sumatra, Kalimantan and Sulawesi. In the framework of this program, from the late 1960s onwards, thousands of farmer families from Java and Bali were resettled in Luwu. ${ }^{7}$

\footnotetext{
${ }^{7}$ The regional office of the Department of Transmigration gives a total number of 69,111 persons for the period 1969-1994. There is no further specification as to area of origin of the transmigrants but the number of settlers from Bali is considerable; my estimation is $40-50 \%$ of this total (source: Kantor Departemen Transmigrasi dan PPH, Kabupaten Luwu, April 1994).
} 


\section{In Search of the Subak}

Being an integral part of the local or regional institutional and administrative landscape, the subak in Bali is prominent and relatively easy to locate. ${ }^{8}$ Looking for the subak in a multi-ethnic sociocultural, agro-ecological and administrative environment outside Bali is not always that easy. What are we actually looking for? The subak as a formal organization with a clearly defined division of tasks and functions and exerting authority over a clearly defined section of an irrigation system? Or might there be other manifestations of the subak as well, less visible in terms of formal organizational presence but influencing local Balinese agricultural practices as well as governmental and farmer-based management arrangements? As I will show in this paper, understanding the role of subak requires attention to both formal organization and institutionalized practices.

In Luwu, Balinese irrigators are only one group among many others. The irrigation systems in which they tend to cultivate their land and from which they get irrigation water have been recently built by, and are partly managed by, the government. When asked about the role of the subak in such systems, most regional and even local government officials of the Irrigation Service can only produce vague commonplaces like 'Balinese are diligent farmers, good at irrigated agriculture and guided by a strong tradition'. There is nobody, however, with even the most basic understanding of subak in local irrigation management. Thus, in the government administrative world the subak remains largely hidden behind the formal structures and arrangements, routines and procedures of state-led irrigation development and management. Therefore, even tracing the subak-and even more so understanding its various local manifestationsrequires in-depth ethnographic research.

\section{Subak as Organizations; Subak as Institutionalized Irrigation Practices}

Soon after I had settled in Kertoraharjo and started research, I discovered how complex the short history of the subak in this Balinese settlement actually was, and how difficult it was to precisely 'locate' the subak in a physical (spatial) or formal organizational sense. Understanding the local history of the subak and its precise role in society required attention to three different, but closely interrelated, domains in which different organizational and institutional manifestations of the subak played a role: first, the formal subak

\footnotetext{
$\overline{8}$ This does not mean that locations, boundaries, rights and responsibilities are not contested; see Spiertz 2000.
}

organizations and the overarching organizational structure of the pekaseh. ${ }^{9}$ Second, the domain of more or less institutionalized irrigation practices based on elements of the Balinese subak, and of newly emerging organizational arrangements developing around small groups of closely related farmers inside the so-called 'tertiary units' (TUs) of the irrigation system. ${ }^{10}$ Third, the water users' associations (WUAs) of the tertiary units (TUs) of the irrigation system, formally established by the government on the basis of a nation-wide blueprint approach to irrigation development. In the following subsections I will trace the role of the subak in these three domains.

\section{Subak Organizations and Pekaseh}

At the time of my research, Kertoraharjo counted four subaks, each with its own governing body but also united in and chaired by a pekaseh. How did these evolve from the period of settlement in 1972-1973, when 500 families350 from Bali and 150 from Java-arrived in the still forested Kalaena area, later to become command area of the current Kalaena irrigation system?

Transmigration is crucially based on the state allocation of land resources to (state-sponsored) settlers. The Balinese transmigrants, arriving in four groups of $150,100,50$ and 50 families respectively, received the standard package of land allocated in the framework of this program: a home yard (pekarangan; 0.25 ha.), a parcel for irrigated agriculture (sawah; 1.00 ha.), and a parcel for rain-fed agriculture (ladang/kebun; 0.75 ha.). Though most families belonging to the same settlement group tended to receive land in more or less the same area, there was not a perfect match between membership of a specific settlement group and location of the land.

This state allocation of land crucially determined the shape and development of the Kertoraharjo subaks. Shortly after their arrival, members of the first settlement group decided to establish a village subak (subak desa). After all groups had settled and had started developing their land, the village subak was split up into four separate subaks, named after the four settlement groups: subak 150KK, subak $100 \mathrm{KK}$, subak 50KK and subak 50KK Tampaksiring. Each was headed by a klian, assisted by other functionaries.

\footnotetext{
${ }^{9}$ The term 'pekaseh' is sometimes used as a synonym for the chairman of the subak, and sometimes for a higher organizational level encompassing more than one subak, as well as for the chairman of such an organization.

${ }^{10}$ Indonesian public irrigation systems tend to be subdivided into an agency-managed part and a farmer-managed part. While the main canal infrastructure (primary and secondary canals) is managed by the Irrigation Service, the tertiary canal system (inside the tertiary unit) is managed by the water users themselves. For this purpose, water users are organized into so-called Water Users' Associations (WUAs).
} 
Together the four subaks form a pekaseh, which is headed by a person with the same title.

With land still partly forest-covered and agricultural activities rainfed, the establishment of the subaks bore no relationship to irrigated agriculture. It was primarily a response to the emerging need for organizational arrangements to stage rituals and make offerings related to developing agriculture, as well as for establishing organizations with a specifically Balinese identity. Therefore, the relationship between subak territory and membership was quite different from Balinese subaks, where there is a more or less clear link, with the irrigation water flow being a major determinant of subak territory and membership. ${ }^{11}$ Subak membership and approximate boundaries in Kertoraharjo were determined by land allocation to the settlement groups rather than by the flow of irrigation water, which did not yet exist. Parcels for (future) irrigated agriculture and for rainfed agriculture allocated to members of the same settlement group were defined as belonging to the same subak, even though these parcels are located in quite different sections of the area of land belonging to the settlement.

In the early 1980s, the irrigation water of the new system reached Kertoraharjo. With the water came a standard package of infrastructure for the so-called 'tertiary units' (TUs) of the system as well as organizational arrangements for tertiary unit management, namely, the water users' associations (WUAs). The introduction of state-devised arrangements for irrigation management was to have important consequences for the role of the subaks. TU construction had been accompanied by a process of obligatory establishment of WUAs. Irrigation management inside the TUs, the layout and construction of which had been fully based on irrigation technical design criteria, had to be taken care of by the obligatory WUAs. After tensions had emerged between the pekaseh-who had introduced rules for local water use and management (awig-awig) associated with subak into the WUAs - and the government administrator responsible for the WUAs, the subaks were forbidden to play a role in tertiary water management. ${ }^{12}$

Basic to these problems and subsequent developments around the subaks was the fact that Balinese farmers and (non-Balinese) government officials hold completely different conceptions of irrigation management. Balinese farmers use the more comprehensive term persubakan to refer to the total domain of irrigated agriculture: its irrigation managerial, agronomic and agricultural, and religious-ritual dimensions.

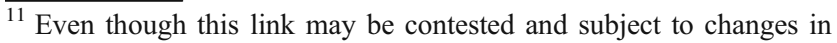
the legal and administrative spheres.

${ }^{12}$ A formal subak role in the TUs with Balinese farmers was, of course, also difficult to realize because some of these TUs had a farmer population that was mixed in ethnic and religious affiliation, while the subak has a 'Balinese only' identity, at least in its ritualreligious dimension.
}

Local government officials, on the other hand, made a distinction between 'management' (manajemen) and 'religion' (agama). In the context of Indonesian irrigation development, tertiary management refers to the performance of routine operation and maintenance tasks (e.g., cleaning of the tertiary canals, small repairs, tertiary water distribution). In the perception of Irrigation Service officials, then, agricultural planning belongs, in sectoral terms, to the Agricultural Service, and religious-ritual aspects of the irrigated rice cultivation cycle are 'religion', not management.

Since subak "interference" in tertiary water management was formally forbidden, the subaks of Kertoraharjo retreated from their activities in the WUA domain (see Roth 2005). Nowadays, the subaks and the pekaseh organize rice rituals, guard ritual purity in the irrigated fields, collect the subak tax (sarin tahun), determine the date of transplanting the rice (pengawitan), and provide cash loans to members. ${ }^{13}$ Determination of the transplanting date forms another potentially sensitive point of interaction, with government schedules for opening and closing of the irrigation system and government agricultural planning: while the government stimulates farmers to transplant as early as possible, the subaks put sanctions upon transplanting before performance of the pengawitan ritual (see Roth 2005, 2006) (Fig. 3).

Contrary to most WUA meetings, subak meetings are well attended (there is a fine for absence). The meetings buzz with activity: collection of seasonal tax and fines, loans and interest; presentation of a financial account; a lottery to distribute subak shares among the members (using a rotating credit system); distribution of loans from the subak funds among members who want to borrow money. There is a lot of excitement, laughing and joking, and most subaks even allow members to play cards or dominoes. One topic is, indeed, strikingly absent in these meetings: the 'watery' part of tertiary water management. No discussions here about water rights and water appropriation, canal cleaning and maintenance, or other water-related issues. These are left to the WUAs of the TUs.

Newly Emerging Practices and Local Group Arrangements Inside the TUs

What do these WUAs actually do? The Indonesian WUA model has been much criticized for focusing on quantitative targets, formal organizational arrangements, routines and bureaucratic procedures rather than on facilitating and stimulating local decision-making and management capacities, flexibility and effective coping with management problems

\footnotetext{
${ }^{13}$ The subak tax, used to cover expenses for subak rituals, is paid in proportion to the area of irrigated land owned. Landowners are responsible for paying it, but can make special arrangements with those who work the land on a temporary basis.
} 


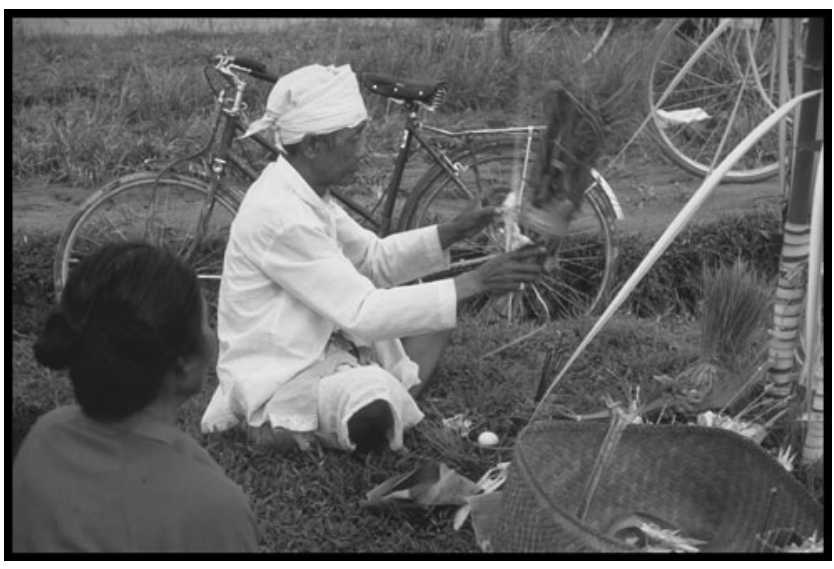

Fig. 3 Subak priest performing the transplanting ritual (photo by author)

(see Bruns 2004, Oad 2001). The same story can, without doubt, be told about the WUAs of the TUs in Kertoraharjo. These tend to be very weak organizations, existing mainly in a formal sense (on paper) but hardly playing an effective role in tertiary management. No meetings are held and, more importantly, no collective field activities carried out. WUAs have no power to enforce rules or impose sanctions, and no strong organizing role in cleaning and repairs and other important irrigation-related activities.

The tertiary systems had been functioning badly from the onset, but degraded further due to the absence of effective management arrangements, tensions between subak and WUA, and the rejection by many Balinese of the engineering solution to water distribution inside the TUs of Public Works systems: the gated water division boxes for rotational irrigation (see also Roth 2005).

Balinese tend to prefer the use of continuous flow systems - which they are familiar with from the subak - to these rotational systems. ${ }^{14}$ Kertoraharjo farmers seemed to have a similar kind of preference. Many farmers explained that they did not like the rotational system, the overflowing of canal embankments if gates are closed, and the crude and non-transparent way of dividing water. Hence many flapgated division boxes were destroyed by removing the flap gates (see Fig. 4). In some places, such destroyed or malfunctioning boxes were replaced by Balinese temuku division structures (see Fig. 5).

The presence of such temukus in some places is a clear physical manifestation of the ways in which forms of subak knowledge and practices influence irrigation management in the TUs of Kertoraharjo. When I did the initial, exploratory field walk-throughs these physical manifestations were, actually, my first clue to the very specific ways in which the subak played a role in irrigation management:

\footnotetext{
${ }^{14}$ For a case study of this non-acceptance of engineering technology in Balinese irrigation systems, see Horst 1996.
}

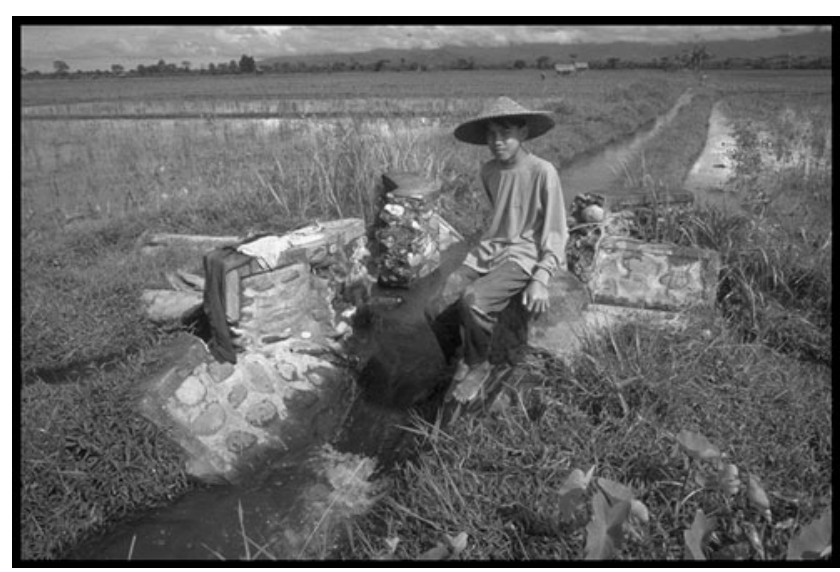

Fig. 4 Degraded TU infrastructure (photo by author)

as an institution, a set of institutionalized practices, patterned farmer behavior steered neither by the WUAs nor by the subaks as formal organizations. How can these developments be related to ways of organizing and forms of collective action that are a necessary condition for their emergence in the first place?

Balinese subak knowledge, norms and practices became the core around which developed new ways of organizing irrigation management: 'from below' rather than from within the formal framework of the WUA. ${ }^{15}$ The basis can be found in small groups of farmers who are dependent on a common water source and who therefore have to negotiate water and management issues like construction, cleaning and repairs, sanctions, etc., whether internally (e.g., with users of the same small canal feeding a section of the TU concerned; see Fig. 6) or externally (e.g., the proportional water division between sections located along the tertiary canal; see Fig. 5).

In some TUs with Balinese farmers, such initiatives for negotiation and cooperation between closely interdependent farmers were given a more permanent organizational shape: small groups of ten to 15 farmers emerged, headed by a leader (kepala kelompok) chosen by the group members. Independently of the WUA, these groups discuss, negotiate and plan cleaning and repairs, contributions for construction, options for small credit (loans) to the members, as well as rules, sanctions and fines. These were laid down in group regulations (awig-awig) based on important values, norms and practices pertaining to subak: regulations for dividing the responsibilities of collective labor, for guarding purity in the irrigated fields, and for appropriating water.

Subak technology (the temuku water division structures) also played a central role in this process. Water division technology is crucial in making the outcome of negotiations about water rights physically and socially sustainable. It is

\footnotetext{
${ }^{15}$ Vermillion (2000) notes the same in his study of two systems in North Sulawesi.
} 


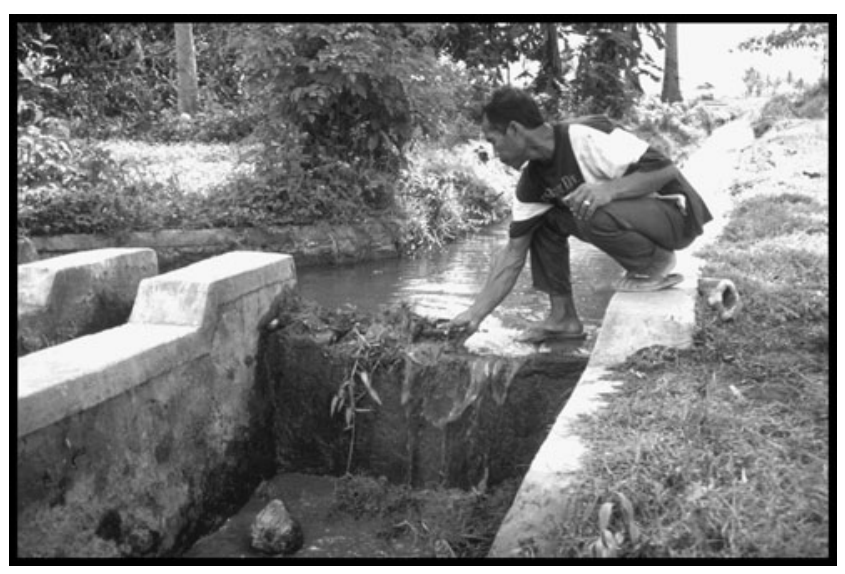

Fig. 5 Farmer-constructed temuku (photo by author)

not a neutral 'thing' but, in the most literal sense, a materialization of norms negotiated and agreed upon by the farmers with de facto decision-making powers about water rights. Such norms also derive from the world of the subak. In contrast, the WUA framework did not allow farmers to renegotiate water distribution and introduce changes in the $\mathrm{TU}$ infrastructure of canals and division works in any way; its major weakness is precisely that it provides no space for such negotiations.

Through the way it is structured, the Balinese temuku gives a clearly visible and transparent water distribution between groups of water users along the tertiary canal. Apart from having constructed stone-cement temukus, some groups also instruct their members to use an easily removable, temporary wooden temuku when taking water from a canal individually. Thus, though formally banned from the organizational space of the WUA, the subak is fully alive in the domain of local irrigation practices and arrangements, becoming visible in organizing practices, knowledge and technology, and 'local law' (von Benda-Beckmann et al. 1996).

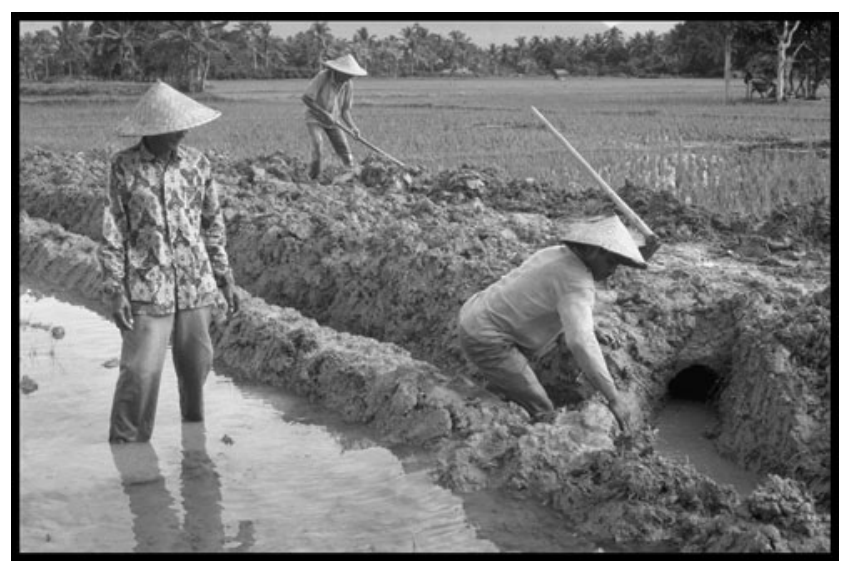

Fig. 6 Farmers negotiating water rights and adapting canals (photo by author)
Institutional Elements of Subak Entering the WUA Organizational Domain

But times are changing, and patterns of landownership change with them. In many TUs with a mixed Balinese and non-Balinese farmer population, a trend towards expanding Balinese landownership is evident. Balinese farmers often buy land, while sellers tend to be Javanese, Toraja or members of the local Pamona population. ${ }^{16}$ The WUA of one such TU, where Balinese had become a large majority and where several small Balinese irrigators' groups had become active, was reactivated by Balinese farmers after having existed on paper only for many years. This WUA became a fully Balinese organization, representing the interests of the Balinese farmer majority in the TU and excluding non-Balinese (Toraja) farmers. ${ }^{17}$ During the meeting at which the WUA was re-established, regulations were introduced that clearly referred to the domain of subak (e.g., awig-awig regulations on purity, contributions for ritual and offerings, etc.). Thus, in some cases the subak 'colonizes' the WUA from the bottom up, turning it more and more into a de facto subak.

\section{Subaks Under Threat: Contesting Subak Authority}

In the above section, I have discussed the ways in which the subak becomes visible in the shape of its locally institutionalized water division knowledge and technology, organizing practices and legal regulations. The specific history of interactions between WUA and the subaks has strongly influenced and restricted the role of the latter as formal organizations. At the same time, the subak plays a much more elusive role as a Balinese institution that (co-) determines the behavior of Balinese irrigators in their local water management activities.

This section deals with another aspect of the subak, namely, its difficult adaptation to local socio-economic processes rather than administrative structures. The relative economic success of Balinese farmers has turned them into active buyers of irrigated land (see note 13). This trend in landownership has been posing new challenges to the Kertoraharjo subaks from the mid-1990s onwards. To understand the problem, we must return to the period when

\footnotetext{
${ }^{16}$ When cocoa was booming in the 1990s many Balinese started buying land in the wider surroundings of the village. In Kertoraharjo, many farmers shifted from a irrigated rice-based farming system to a system based on a combination of irrigated rice and cocoa gardening. Only a minority fully shifted from an irrigated rice-based system to a cocoa-based system.

${ }^{17}$ As most Toraja water users had never been active in the WUA and government officials tend to be very far away, this Balinese 'coup' had no immediate repercussions.
} 
the subaks were established. Initially, the membership of the subaks was defined on the basis of land allocation to the transmigrants. The duties attached to subak membershipprimarily the payment of subak tax and rice transplanting in accordance with the schedule determined by subaks and pekaseh - though somewhat contested, are supported by the large majority of Balinese farmers engaged in irrigated agriculture.

Problems have arisen mainly about those land resources that were not initially defined as subak land: land bought by Balinese from non-Balinese landowners based in the villages around Kertoraharjo. As a result of the expansion of Balinese landownership, the fringes of 'Balinese' land have become more fuzzy. This process has introduced ambiguities in the definition of subak authority, membership, rights and responsibilities. This ambiguity has become a resource in disputes about rights and responsibilities attached to subak membership. Should owners of 'new' land pay subak tax and carry other burdens of subak membership, like labor contributions and attending meetings? Should such landowners accept the transplanting date determined by the pekaseh?

The subaks claim legitimate authority over all irrigated land resources owned by farmers from Kertoraharjo. The subak leaders and pekaseh legitimize this point of view by pointing out that the ritual services performed by the subaks for the benefit of Balinese farmers and crops know no such spatial boundaries. As all farmers benefit, all have to contribute to their funding as well, whatever the location of the land. However, this subak claim to legitimate authority over irrigated fields outside the area initially allocated to the transmigrants and over the Kertoraharjo farmers who own this land is utterly contested.

The tensions and conflicts arising from these contradictory definitions of areas of subak jurisdiction have put new pressures on the subaks. The wide variety of specific conditions claimed by Balinese landowners to legitimize exclusion of their purchased land from the subaks is a source of fierce debate: should all irrigated land owned by Balinese from the customary village (desa adat) of Kertoraharjo be under subak regulation? Should farmers be allowed to adapt their planting schedule to local circumstances? Should Balinese who were not transmigrants (and so never became a member of the initial subaks) but arrived and settled at their own initiative, be members of the subak? Who is responsible for payment of the subak tax if Balinese land is worked under leasehold by a non-Balinese farmer? These are all complex questions, to which the subak regulations have no answers.

While the issue of tax payment and other contributions can be interpreted as a free rider problem, the question whether or not to follow the subak-determined transplanting date is much more complex. There are marked differences in timing of the various stages and activities of the rice cultivation cycle between the different villages and settler groups. For farmers who have bought irrigated land in 'non-Balinese' locations, adaptation to these local patterns is absolutely crucial. Transplanting later than one's neighbors, for instance, means that final land preparation (e.g., levelling) will also take place later. However, for plows to gain access to fields surrounded by land already planted with rice is difficult or impossible without damaging the crop. The increased risk of plague damage is another argument in favor of adapting to the locally prevalent pattern.

As such contestations of subak authority are primarily about the status of 'new' land (land not originating from the land allocation by the state to the transmigrants), those involved tend to be primarily people who bought such land: offspring of the original settlers and migrants who arrived and settled spontaneously. However, original transmigrants who bought new land are sometimes also involved. According to some subak leaders, enforcement is weak because the subaks do no longer control the resource that can be most effectively used for sanctioning: water.

\section{A Nearby Balinese Village: The Subak in Alam Buana}

\section{Alam Buana: A Tail-end Village}

In the foregoing sections I have discussed the subak in Kertoraharjo. In this section, I show that even within a very small geographical area, subaks can be highly diverse institutions. As this case makes clear, any a priori conceptualization of what subak 'really is' seems to miss the point of its basic adaptability to specific local agroecological contexts, location in the irrigation system, historically generated conditions, relationships and organizational-institutional landscapes.

Located close to Kertoraharjo, Alam Buana is an allBalinese transmigration settlement that filled up the residual land available for settlement in the right-bank part of the Kalaena irrigation area (see Fig. 2). In 1978, 100 transmigrant families from Bali arrived in transmigration unit Karambua III. Later, this settlement became the administrative village of Alam Buana. In the late 1990s the village had a population of some 130 households (610 people). Its land resources then consisted of 105 ha of sawah, 75 ha of ladang (rainfed agricultural land) and 30 ha of home yards.

Alam Buana is situated in the tail-end of this part of the Kalaena irrigation system, where neither irrigation nor drainage water are sufficiently controlled. This unfavorable position works out differently for the two main areas of agricultural land belonging to the village: one is located in the northeastern part, the other in the southwestern part of the village. In fact, the village is doubly disadvantaged: the 
northeastern part of the village land receives more than its share of drain water due to the failure of the drainage system. More than 85 ha of the sawah and ladang areas are regularly flooded or too marshy to be used at all. ${ }^{18}$ Especially in periods of high rainfall, farmers who own land in this part of the village suffer from severe crop damage caused by flooding. During dry periods, on the other hand, this part of the agricultural land of Alam Buana is short of irrigation water. During construction only part of the land was provided with irrigation infrastructure. Though the Public Works map shows no differences with surrounding villages, some of the structures and canals depicted on it do not function, while construction works never reached part of the land resources of this village. Farmers in this section take water from a drain by means of a small removable weir constructed at the initiative of the local subak.

Farmers owning land in the southwestern part of Alam Buana are not disturbed by such problems of flooding. However, they can hardly take advantage of this, due to their unfavorable position (in a tail-end section) in the irrigation system. This part of the village land receives too little irrigation water from the system, and too late in the season. Hence, the farmers are continuously confronted with water shortages that form a serious threat to their crops.

\section{The Subak in Alam Buana}

In contrast to Kertoraharjo, in Alam Buana only a small part of the village land was provided with-badly functioning-irrigation infrastructure, TUs and WUAs. The WUAs only exist on paper. It is striking that in this village the subak has retained its broad range of functions that comprises construction, water management, the cycle of agricultural ritual and offerings, and agricultural decisionmaking. As it was 'given up' by the Irrigation Service at an early stage, no tensions and conflicts arose here between the government program for WUA development and local Balinese ways of managing irrigated agriculture.

The village has one subak, which is optimistically called Sri Nadi (roughly glossed as 'harvest will succeed'). The subak head is called pekaseh here. In the beginning of the new rice season, every day when the village gong is struck, all members gather for collective labor. A small shrine for ritual and offerings associated with rice cultivation stands at

\footnotetext{
${ }^{18}$ This is borne out by the existence of big differences for most inhabitants between their total landownership and the part of it that can actually be productively used. While many Kertoraharjo farmers were able to sell increasing amounts of surplus harvest on the market and invest in additional land for irrigated rice and/or cocoa, their neighbors in Alam Buana have to subsist on the meagre proceeds of rice cultivation on those parts of their land that can be used. Unable to produce any surplus, they have remained almost fully dependent on their initial low-quality land.
}

the southern foot of a hill near the village. Unlike the people in Kertoraharjo, the Alam Buana population cannot yet afford a complete subak temple. Determination of a date for transplanting takes place in the same way as in Kertoraharjo: after opening and closure dates of the system have been announced at a government-organized meeting at the subdistrict level (the so-called 'tudang sipulung' meetings), ${ }^{19}$ another meeting is held in the village, in which a date for starting transplanting the paddy, determined on the basis of religious, agronomic and other considerations, is proposed to the members. Contrary to what happens in Kertoraharjo, this meeting has a public character.

However, due to their problematic position in the irrigation system, farmers owning and working land to the northeast of the village (where floods regularly destroy the rice crop) do not often follow the planting schedule determined by the government. Whenever they see a chance for transplanting (or replanting after a flood), they do so. Almost every wet season harvest is either a complete failure or requires replanting once or even twice. Dry season harvests stand a greater chance of success. In view of these problems, farmers in this area are exempted from following the planting regulations of the subak. They are allowed to plant or replant whenever they need to. Southwest of the village, farmers have to follow the transplanting schedule. Those who plant the normal rice varieties are given 2 weeks for transplanting, those who plant the very fast-growing varieties another 2 weeks.

As a consequence of the shortage of cultivable land, Alam Buana has no customary village land (pelaba). The transplanting ritual is held on the private land of the village priest. Contrary to the case in the Kertoraharjo subaks, where the new rice cultivation season is opened by the socalled 'mapag toya' ritual, ${ }^{20}$ in Alam Buana the transplanting ritual is the first one in the cultivation cycle. Where access to water from the irrigation canals is very difficult due to the tail-end position of the village, most fields are rain-fed rather than irrigated. Whenever there is some water in the canals and farmers need it, they are allowed to take it in accordance with subak rules for diverting water; the 'welcoming the water' ritual has no meaning here.

The subak of Alam Buana is subdivided into three groups (kelompok, tempekan), each managing part of the irrigated fields and headed by a klian tempekan. Within the

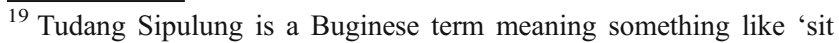
and discuss together'. It is used by the government to give (top-down) decision-making on the opening and closure of irrigation systems a participatory and 'bottom-up' flavor.

20 'Welcoming the water'; the arrival of the first irrigation water is accompanied by this ritual. As it has to be preceded by canal cleaning and repairs, such ritual activity often structures the important irrigation managerial activities.
} 
severe limitations posed by the physical conditions in this section of the Kalaena irrigation area, rules are applied for water distribution in times of water scarcity. These concern the width of the field inlet relative to its position along the canal, the water source, the number of users and the irrigated area. All members have collective labor obligations. Whoever owns (and actually works) more than the 'standard' size (areal patokan) for labor obligations, i.e., half a hectare of irrigated fields, has to pay a certain amount of cash per quarter hectare of additional land.

Routine subak meetings are held once a month. Such subak meetings in Alam Buana make a far more formal impression than those in Kertoraharjo: no card-playing and other recreation, a more formal opening of the meeting, and the presence of the (Balinese) administrative village head. There is stricter control of active member participation in rituals (absence is fined), and greater subak influence on non-irrigated agriculture: farmers cultivating rain-fed crops have to join in and contribute equally to the subak rituals. In these meetings, all matters concerning agricultural planning, rituals and irrigation can be discussed. During a meeting I attended, farmers discussed conflicts with a neighboring village about the construction of a weir in a drain, on which the Balinese residents of Alam Buana are dependent for water. They also discussed issues like farmer contributions to construction, subak development and ritual funds, collection of the subak tax (like in Kertoraharjo, ten kilos of unhulled rice per hectare per season), member loans and return of loans with interest, preparations for a rice ritual to be held, and discussions initiated by the administrative village head about a land titling program by the Land Registry Agency (BPN) and the financial consequences of titling for the farmers.

\section{Conclusion: The Many Faces of Subak in a Migrant Setting}

In this paper I have traced the history, development and current role of the subak in a Balinese transmigrant society. The subaks of Kertoraharjo were established and developed under the specific conditions pertaining to this kind of pioneer settlement. After the establishment of subaks, mainly for the purpose of organizing agricultural rituals in an environment full of threats to the crops of the settlers, it took about 10 years more for irrigation infrastructure to reach the Balinese village. This was not a neutral process: irrigation development meant the introduction of a TU-structure and associated organizational arrangements, the WUAs.

Contrary to the situation in Bali, where the subak enjoys formal recognition by the government authorities, here the subaks were established and operate outside the domain ofand unrecognized by — government administration. The values, norms, rules and regulations associated with the subak interact in a complex way with government policies, rules, regulations, and organizational arrangements pertaining to local irrigation management in a government-operated system. This legally plural condition is the unplanned outcome of processes of transmigration and resettlement, combined with irrigation development in the multi-ethnic landscape created by these processes.

As the case study of the subaks in Kertoraharjo shows, this made for uneasy coexistence of, and interactions between the subaks and the WUAs. When the knowledge, norms and organizational arrangements associated with the subak started to influence the newly established WUAs, the subak functionaries were forbidden to deal with those irrigation management matters that formally belonged to the WUA domain. From then on, the subaks and pekaseh focused on the religious-ritual and agricultural planning dimensions of irrigated agriculture, but left the more instrumental part of irrigation management to the WUAs.

This did not mean the end of the role of subak in irrigation: subak as an institution, a set of specific forms of knowledge, norms, and organizational arrangements started developing 'from below'. This role of subak, tied neither to the subak organization nor to the WUAs in a direct sense and hence not 'visible' through a lens that is focused on formal organizational structures, becomes manifest in local negotiations about water, construction of division structures, use of small implements for water appropriation, the emergence of organizational arrangements among farmers with a stake in the same canal, and creation of small bodies of rules. In some cases, these norms, arrangements and practices can be seen to enter the WUA organizational domain and even to become institutionalized there to some extent.

In the meantime, the subak organizations developed in their own specific ways, influenced by broader trends in Balinese landownership. In Kertoraharjo, the expansion of Balinese landownership to areas outside the initial subak domains - the land resources allocated by the state to the transmigrants - has caused the definitions of subak membership and associated bundles of rights and responsibilities to become increasingly fuzzy and ambivalent. Like the earlier separation of 'management' (the WUA domain) from 'religion' (the subak domain), this has become another serious challenge to the long-term social sustainability of the subak organizations.

In nearby Alam Buana, where the Balinese inhabitants find a meager subsistence in irrigated agriculture on the fringes of the irrigation system, the subak has never been restricted in its functioning by competing claims of authority from the state-established TU and WUA structure. Alam Buana was largely left to solve its own irrigation and drainage problems. This greater institutional room for maneuver in Alam Buana compared to Kertoraharjo 
resulted in the subak occupying a more central place in the former village. However, hydrological and irrigationtechnical problems are too severe for the subak ever to be able to play a major role in solving them.

The comparative case of Alam Buana leads to an important conclusion about the uneasy relationship between state (WUA) and non-state (subak) institutional arrangements. In Kertoraharjo, where state arrangements are, to some extent, enforced and alternative institutions marginalized, the subak will probably remain a kind of shadow institution unrecognized by the state, whatever its impact on and importance for Balinese irrigation practices. In Alam Buana, the almost total absence of the state agency in irrigation matters meant more room for the subak. The conclusion can be that, at least in this setting outside Bali, the institutional opportunities for the subak are inversely related to the presence of government arrangements and institutions.

It can finally be concluded, then, that subaks in and around Kertoraharjo have many faces. In Kertoraharjo itself, their development as formal organizations was crucially influenced by the presence of WUAs. This put the subaks on another track, away from the instrumentalities of water management and running into the problem of legitimacy under the influence of changing landownership. But as an institution, a determinant of farmer behavior in the daily practices of irrigation management, its subak is fully alive. Alam Buana, the neighboring village, serves as a case to point out that, just next door, things can be quite different again. I hope that my analysis of the many ways in which the subak becomes manifest has shown that it is impossible to find 'the' subak, much less to ascribe all kinds of predefined purposes and functions to it and evaluate its functioning in terms of such normative ascriptions by observers or policy-makers.

Open Access This article is distributed under the terms of the Creative Commons Attribution Noncommercial License which permits any noncommercial use, distribution, and reproduction in any medium, provided the original author(s) and source are credited.

\section{References}

Boelens, R. (1998). Collective management and social construction of peasant irrigation systems: conceptual introduction. In Boelens, R., and Dávila, G. (eds.), Searching for Equity. Conceptions of Justice and Equity in Peasant Irrigation. Van Gorcum, Assen, pp. 81-99.

Boelens, R., and Zwarteveen, M. (2002). Gender dimensions of water control in Andean irrigation. In Boelens, R., and Hoogendam, P. (eds.), Water Rights and Empowerment. Van Gorcum, Assen, pp. 75-109.

Boon, J. A. (1977). The Anthropological Romance of Bali 15971972. Dynamic Perspectives in Marriage and Caste, Politics and Religion. Cambridge University Press, Cambridge.
Booth, A. (1977). Irrigation in Indonesia, part I. Bulletin of Indonesian Economic Studies 13(2): 33-74.

Bruns, B. (2004). From voice to empowerment: Rerouting irrigation reform in Indonesia. In Mollinga, P. P., and Bolding, A. (eds.), The Politics of Irrigation Reform. Contested Policy Formulation and Implementation in Asia, Africa and Latin America. Ashgate, Aldershot, pp. 145-165.

Bruns, B., and Meinzen-Dick, R. (eds.) (2000). Negotiating Water Rights. Intermediate Technology Publications/International Food Policy Research Institute, London.

Charras, M. (1982). De la Forêt Maléfique a l'Herbe Divine. La Transmigration en Indonésie: les Balinais a Sulawesi. Editions de la Maison des Sciences de l'Homme, Paris.

Davis, G. J. (1976). Parigi: a Social History of the Balinese movement to Central Sulawesi, 1907-1974. University Microfilm International, Ann Arbor, Michigan, USA.

Falvo, D. J. (2000). On Modelling Balinese Water Temple Networks as Complex Adaptive Systems. Human Ecology 28(4): 641-649.

Geertz, C. (1972). The Wet and the Dry: Traditional Irrigation in Bali and Morocco. Human Ecology 1(1): 23-29.

Geertz, C. (1980). Organization of the Balinese Subak. In Coward Jr., E. W. (ed.), Irrigation and Agricultural Development in Asia. Perspectives from the Social Sciences. Cornell University Press, Ithaca and London, pp. 70-90.

Happé, P. L. E. (1935). Waterbeheer en Waterschappen. De Ingenieur in Nederlandsch-Indië 2 (11), VI: 135-140.

Horst, L. (1996). Intervention in irrigation water division in Bali, Indonesia. A case of farmers' circumvention of modern technology. In Diemer, G., and Huibers, F. (eds.), Cropsm People and Irrigation. Water Allocation Practices of Farmers and Engineers. Intermediate Technology Publications, London, pp. 34-52.

Howe, L. (2006). Review article of Stephen Lansing: Perfect Order: Recognizing Complexity in Bali. Anthropological Quarterly 79 (4): 777-782.

Korn, V. E. (1924). Het adatrecht van Bali. De Ster, 's Gravenhage.

Lansing, J. S. (1987). Balinese "Water Temples" and the Management of Irrigation. American Anthropologist 89: 326-341.

Lansing, J. S. (1991). Priests and Programmers. Technologies of Power in the Engineered Landscape of Bali. Princeton University Press, Princeton, New Jersey.

Liefrinck, S. A. (1969). Rice Cultivation in Northern Bali. In Swellengrebel, J. L. (ed.), Bali: Further Studies in Life, Thought, and Ritual. W. van Hoeve, The Hague, pp. 3-73.

Meinzen-Dick, R. S., and Pradhan, R. (2001). Implications of Legal Pluralism for Natural Resource Management. IDS Bulletin 32(4): $10-17$.

Mollinga, P. P. (2003). On the Waterfront. Water Distribution, Technology and Agrarian Change in a South Indian Canal Irrigation System. Wageningen University Water Resources Series, Orient Longman, Hyderabad, India.

Oad, R. (2001). Policy Reforms for Sustainable Irrigation Management - a Case Study of Indonesia. Irrigation and Drainage 50: 279-294.

Roth, D. (2005). In the shadow of uniformity. Balinese irrigation management in a Public Works irrigation system in Luwu, South Sulawesi, Indonesia. In Roth, D., Boelens, R., and Zwarteveen, M. (eds.), Liquid Relations, Contested Water rights and Legal Complexity. Rutgers University Press, New Brunswick, pp. 66-96.

Roth, D. (2006). Which Order? Whose Order? Balinese Irrigation Management in Sulawesi, Indonesia. Oxford Development Studies 34(1): 33-46.

Schulte Nordholt, H. (1986). Bali: Colonial Conceptions and Political Change 1700-1940. From Shifting Hierarchies to 'Fixed Order'. CASP, Rotterdam.

Schulte Nordholt, H. (1996). The Spell of Power. A History of Balinese Politics, 1650-1940. KITLV Press, Leiden. 
Spiertz, H. L. J. (1991). The Transformation of Traditional Law: a Tale of People's Participation in Irrigation Management on Bali. Landscape and Urban Planning 20: 189-196.

Spiertz, H. L. J. (2000). Water rights and legal pluralism: some basics of a legal anthropological approach. In Bruns, B. R., and Meinzen-Dick, R. S. (eds.), Negotiating Water Rights. International Food Policy Research Institute, New Delhi, pp. $245-268$

Sutawan, N. (1998). Peranan Subak di Era Reformasi. Dinamika Petani. Media Informasi tentang Sumberdaya Air dan Pertanian, Diterbitkan untuk Jaringan Komunikasi Irigasi Indonesia. No. 32, Tahun X.

Sutawan, N., Swara, M., Windia, W., Suteja, W., Arya, N., and Tjatera, W. (1990). Community-Based Irrigation Systems in Bali. In Gooneratne, W., and Hirashima, S. (eds.), Irrigation and Water Management in Asia. Sterling Publishers Private Limited, New Delhi/Bangalore, pp. 81-147.

Vermillion, D. L. (1986). Rules and Processes: Dividing Water and Negotiating Order in Two New Irrigation Systems in North Sulawesi, Indonesia, Ph.D. Thesis.
Vermillion, D. L. (2000). Water Rights in the state of nature: emergent expectations in an Indonesian settlement. In Bruns, B. R., and Meinzen-Dick, R. S. (eds.), Negotiating Water Rights. International Food Policy Research Institute, New Delhi, pp. 56-82.

Vincent, L. (2001). Struggles at the social interface: developing sociotechnical research in irrigation and water management. In Hebinck, P., and Verschoor, G. (eds.), Resonances and Dissonances in Development. Actors, Networks and Cultural Repertoires. van Gorcum, Assen, pp. 65-81.

von Benda-Beckmann, F., and von Benda-Beckmann, K. (2006). The Dynamics of Change and Continuity in Plural Legal Orders. Journal of Legal Pluralism and Unofficial Law 53-54: 1-44.

von Benda-Beckmann, F., von Benda-Beckmann, K., and Spiertz, J. (1996). Water rights and policy. In Spiertz, J., and Wiber, M. G. (eds.), The Role Of Law In Natural Resource Management. VUGA, 's, Gravenhage, pp. 77-99.

von Benda-Beckmann, F., von Benda-Beckmann, K., and Wiber, M. G. (2006). The properties of property. In von Benda-Beckmann, F., von Benda-Beckmann, K., and Wiber, M. G. (eds.), Changing Properties of Property. Berghahn Books, New York and Oxford, pp. 1-39. 